\title{
1 Bacterial biofilm formation on soil fungi: a widespread ability under controls
}

2

3 Cora Miquel Guennoc ${ }^{1,2}$, Christophe Rose ${ }^{3}$, Jessy Labbé2, Aurélie Deveau ${ }^{1 *}$

4

5

6

7

81 INRA Université de Lorraine, Interactions Arbres-Microorganismes, UMR 1136, Champenoux, F-

954280 , France

102 Biosciences Division, Oak Ridge National Laboratory, Oak Ridge, TN 37831, USA

113 INRA Université de Lorraine, Ecologie et Ecophysiologie Forestière, UMR 1137, Champenoux, F-

1254280 , France

13

14

15

16

17

18

19

20 *Corresponding author: Mailing address: UMR1136 INRA Université de Lorraine, Interactions Arbres

21 Micro-organismes, 54280 Champenoux, France. Phone: +33 3833940 88, Fax: +33 383394069 .

22 E-mail: aurelie.deveau@inra.fr

23 


\section{Abstract}

25

26 In natural environments, bacteria preferentially live in biofilms that they build on abiotic surfaces but also

27 on living tissues. Although fungi form extensive networks of hyphae within soils and thus could provide

28 immense surfaces for bacteria to build biofilms and to proliferate, the extent on such phenomenon and

29 the consequences for the fitness of both microorganisms is poorly known in soils. Here, we analyzed

30 the process of formation of biofilms by various bacteria on hyphae of soil fungi in an in vitro setting using

31 confocal and electron microscopy. We showed that the ability to form biofilms on fungal hyphae is

32 widely shared among soil bacteria. In contrast, some fungi, mainly belonging to the Ascomycete class,

33 did not allow for the formation of bacterial biofilms on their surfaces. The formation of biofilms was also

34 strongly modulated by the presence of tree roots and by the development of the ectomycorrhizal

35 symbiosis, suggesting that biofilm formation does not occur randomly in soil but that it is highly

36 regulated by several biotic factors. Finally, our study led to the unexpected finding that networks of

37 filaments made of extracellular DNA were used to build the skeleton of biofilms by a large array of

38 bacteria.

43 Keywords: biofilm, eDNA, ectomycorrhizal symbiosis, soil fungi, fungal/bacterial interactions

Statistics

Abstract. 200 words (200 max)

47 Main text. 4332 words (5000 max)

48 Figures \& Tables. 2 Tables, 6 figures

49 Supplemental Figures \& Tables. 4 figures, 1 table.

50 References.56 (100 max) 
51

52

53

54

55

56

57

58

59

60

61

62

63

64

65

66

67

68

69

\section{Introduction}

Among the myriad of organisms that live in forest soils, bacteria and fungi largely exceed their counterparts in terms of abundance and diversity (Nazir et al., 2010). Both highly contribute to the decomposition of soil organic matter and to the nutrient cycling and thus have a key role in the modulation of soil fertility and productivity (Rousk and Bengtson, 2014; Lindahl and Tunlid, 2015). In addition, some mutualistic fungi called mycorrhizal fungi, act as providers of carbon sources to the soil and of nutrients to the trees through the symbiosis they establish with roots (Smith and Read, 2008).

In soil, many bacteria and fungi often occupy a shared microhabitat and there, many bacteria often colonize the surface of fungal hyphae, also called "hyphosphere" (Frey-Klett et al., 2011). Bacteria are thought to gain two main benefits from this association. First, the hyphosphere provide a nutritional source for bacteria that either consume nutrients released directly or indirectly by hyphae, or directly prey on fungi (Leveau and Preston, 2008; Hover et al., 2016). Second, fungal hyphae can serve as vectors for bacteria to travel across the soil and to reach otherwise inaccessible nutrient sources (Nazir et al., 2010). These so called "hyphal highways", can be followed by bacteria that swim along the water film that covers the hyphae, or by bacteria that settle at the tip of the growing hyphae (Otto et al., 2016; Warmink and van Elsas, 2009). Conversely, some fungi can benefit from the metabolic activity of their associated bacteria (Li et al., 2016), gain protection against stresses (Nazir et al., 2014) or even "farm" bacteria to later use them as a source of nutrients (Pion et al., 2013). However, this close interaction between fungi and bacteria can also be detrimental to the fungi and a number of them produces defensins to prevent the bacterial colonization of their hyphae (Essig et al., 2014).

Bacteria can establish in the hyphosphere in three states: as free-living cells, as attached single cells or as organized biofilms. Biofilms arise through the aggregation of bacterial cells and their embedding into a self-produced matrix of extra polymeric substances (Flemming et al., 2016). Life as a biofilm has the double advantages to increase the bacterial resistance against biotic and abiotic stresses, and to permit the organization of cells into functional sub-communities. As a consequence, a large number of bacterial species have developed the ability to build biofilms on hydrated abiotic surfaces (e.g. water pipes, medical devices...) but also on living tissues (e.g. epithelial cells, root surfaces...). Fungal hyphae can also support bacterial biofilms and in vitro formation of bacterial biofilms on hyphae of some soil Ascomycetes, Basidiomycetes and Zygomycetes has been reported (Scheublin et al., 2010; Burmølle et al., 2012; Hover et al., 2016; Nazir et al., 2014). Yet, while soil fungi offer relatively close habitats to bacteria, different behaviors exist between soil fungal species. Since bacterial biofilms are frequent on sporocarps of ectomycorrhizal (ECM) fungi but rare on saprotrophic ones, it has been proposed that the trophic status (i.e. symbiotic vs saprotrophic) of the fungi drives the interactions (de Carvalho et al., 2015). As being in competition for carbon sources, saprophyte would be 
85 more intolerant to bacteria than mycorrhizal fungi that get their carbon from their plant partner. However,

86 this hypothesis has not been tested on hyphae yet. Conversely, differences among bacteria in their

87 ability to form biofilms on hyphae have been pointed in the arbuscular mycorrhizal (AM) fungi

88 Rhizophagus intraradices and Glomus sp. (Toljander et al., 2006; Scheublin et al., 2010) suggesting a 89 potential fine-tuned interaction between these fungi and bacteria during the process of biofilm formation.

90 Specific bacterial communities also preferentially associate with ECM fungi (Frey-Klett et al., 2005;

91 Warmink et al., 2009). Among the ECM associated bacteria, Mycorrhiza Helper Bacteria (MHB) have

92 received a lot of attention because of their ability to stimulate mycorrhiza formation and functioning

93 (Deveau and Labbé, 2017). Some of them have been shown to form biofilm-like structure on ECM fungi 94 although the extent of such interactions is unknown (Frey-Klett et al., 2007). Because ECM fungi 95 colonize very large volumes of soil, they could provide large surfaces for bacteria to establish as 96 biofilms. Altogether, these data suggest that biofilm formation on fungal hyphae could be an important 97 phenomenon in soil. However, we have little information on the frequency of such event, its level of specificity among microorganisms and the biotic and abiotic parameters that drive the fate of the interaction. Such knowledge is key to predict how soil fungi and bacteria behave in soils.

To fill this gap, we characterized in depth the biofilms formed by several MHBs and other soil bacteria on hyphae of the model ECM fungus Laccaria bicolor S238N (Martin et al., 2008) using an in

102 vitro set up (Miquel Guennoc et al 2016). We then evaluated the impact of the root system and of the 103 ectomycorrhizal symbiosis on the fate of the interaction. Lastly, we tested the impact of the trophic 104 status and the taxonomic origin of soil fungi on the establishment of biofilms. Our data suggest that 105 biofilm formation on hyphae does not occur randomly but then it is regulated by several biotic factors. In 106 addition, the detailed study of the structure of the bacterial biofilms revealed an unexpected feature that 107 is likely to be widespread: the use of extracellular DNA filaments to build the skeleton of biofilms.

108

109

110

111

112

113 All the strains used in this study are listed in Table 1. GFP-tagged versions of Pseudomonas 114 fluorescens BBc6 (Deveau et al., 2010), Burkholderia ginsengisoli E3BF7_7 and Dyella sp. E3BF9_7 115 were used to facilitate imaging. None of the other microbial strains used in this study constitutively 116 expressed a fluorescent protein. Bacterial strains were maintained at $-80^{\circ} \mathrm{C}$ in Luria-Bertani (LB) 117 medium with $30 \%$ glycerol and were first grown on $10 \%$ tryptic soy agar (TSA)-plates for $24 \mathrm{~h}$ ( $3{\mathrm{~g} . \mathrm{I}^{-1}}^{-1}$ 118 tryptic soy broth from Difco and $15 \mathrm{~g} . \mathrm{l}^{-1}$ agar) at $28^{\circ} \mathrm{C}$. Then, for each strain, 2 to 3 individual bacterial 119 colonies were collected from TSA cultures to inoculate $25 \mathrm{ml}$ of liquid LB medium and incubated at 
$12028^{\circ} \mathrm{C}$ and $150 \mathrm{rpm}$ until late exponential growth before their use for biofilms formation. Fungal cultures

121 were maintained on P5 medium then transferred to P20 agar plates covered with EDTA pre-treated

122 cellophane membranes as described by Miquel Guennoc et al. (2016), except for Tuber melanosporum

123 that was always kept on P20 medium.

124

125 In vitro biofilm formation on fungal hyphae and glass fibers

126 The method described step-by-step in Miquel Guennoc et al. (2016) was used. Briefly, bacterial cultures

127 in late exponential growth phases were spin down and washed once in potassium phosphate buffer

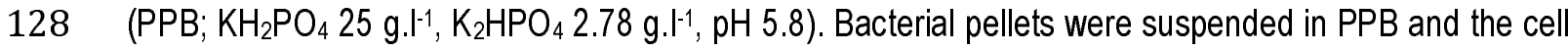

129 density was adjusted to $10^{9} \mathrm{cfu}^{\mathrm{ml}-1}$ to prepare the bacterial inoculum. Five $\mathrm{ml}$ of this bacterial

130 suspension was added to each well of 6 well-microplates. Then, using sterile tweezers, $1-\mathrm{cm}$ diameter

131 fungal colonies grown on P20-agar plates were added to each well of the microplates. The cellophane

132 membranes on which they were growing were kept to avoid harming fungal hyphae during the transfer.

133 Plates were gently shaked for $1 \mathrm{~min}$ to allow the fungus to unstick from the cellophane sheets and

134 cellophane sheets were removed from each well. These resulting microplates with the bacterial and

135 fungal inocula were incubated at $20^{\circ} \mathrm{C}$ and $60 \mathrm{rpm}$ for $16 \mathrm{hrs}$, except if otherwise stated. To test for

136 biofilm formation on dead fungal colonies, 1-cm diameter growing fungal colonies were dipped into

137 either $3 \%$ paraformaldehyde solution for an hour or progressive ethanol baths for 3 min each $(20 \%$,

$13850 \%, 70 \%, 100 \%$ ), then washed three times with PPB to remove traces of paraformaldehyde or

139 ethanol, . Dead colonies were then immediately used to test for biofilm formation using same protocol

140 as above. To test the formation of bacterial biofilm on glass fibers, fungal colonies were replaced by 10 -

$141 \mu \mathrm{m}$ diameter sterile glass fibers. For each treatment, two independent assays in triplicate were

142 analyzed.

143

144 Sample preparation for confocal and electron microscopy imaging

145 Samples for imaging were prepared following the methodology described in Miquel Guennoc et al.

146 (2016). Briefly, fungal colonies or glass fibers were transferred to a new microplate. Then, samples were

147 rinsed with $\mathrm{NaCl}\left(17 \mathrm{g.l}^{-1}\right)$ and with PPB to detach planktonic and electrostatically attached bacterial

148 cells (Toljander et al., 2006).

149 For confocal imaging, fungal colonies were cut in half with a razor blade, stained then mounted on slide

150 with Fluoromount-G anti-fading (Fisher Scientific). Fungal hyphae were stained with $10 \mu \mathrm{g} \cdot \mathrm{ml}^{-1}$ Wheat

151 Germ Agglutinin coupled to Alexa Fluor 633 (WGA-633, Thermofisher Scientific) for $15 \mathrm{~min}$. All bacteria,

152 except $P$. fluorescens BBc6, B. ginsengisoli E3BF7_7 and Dyella sp. E3BF9_7 that constitutively

153 expressed GFP, were stained with $0.3 \mu \mathrm{M}$ 4',6-Diamidino-2-Phenylindole (DAPI, Thermofisher 
154 Scientific) for $15 \mathrm{~min}$. Several dyes were used to visualize matrix components: 1X SYPRO Ruby (15 min 155 incubation; Thermofisher Scientific), DAPI, prodidium iodide $\left(1 \mu \mathrm{g} \cdot \mathrm{ml}^{-1}, 15\right.$ mins; Thermofisher Scientific) 156 or TO-PRO-3 ( $1 \mu \mathrm{M}, 15$ mins; Thermofisher Scientific) were used to stain proteins and extracellular 157 DNA (eDNA), respectively (Suppl. Table 1). Confocal imaging was performed with a LSM780 Axio 158 Observer Z1 laser scanning confocal microscope (LSCM, CarlZeiss), equipped with 405, 488 and 633 $159 \mathrm{~nm}$ excitation lasers and T-PMT and GaAsp PMT detectors, coupled to ZEN 2.1 lite black software 160 (CarlZeiss). For all experiments, images were captured with 10x 0.3 NA objective to obtain a complete 161 view of one fourth of the fungal using a combination of tile scan and $Z$ stack functions ( $5 \times 5$ fields over 162 the entire depth of the fungal colony). Then images were taken with a 40x 1.2 NA objective to obtain 163 high resolution zoom images of representative events within the imaged captured at 10x. Data 164 visualization was performed by 2D maximum intensity projection, using the "Z project" function from Fiji 165 free software ((Schindelin et al., 2012), http://fiji.sc/Fiii).

166 For electron microscopy imaging, fungal colonies or glass fibers were first rinsed with $\mathrm{NaCl}\left(17 \mathrm{~g} . \mathrm{I}^{-1}\right)$ and 167 with sterile water to avoid crystal formation during dehydration step. Then, samples were dehydrated by 168 freeze-drying and coated with $2 \mathrm{~nm}$ of platinum (quartz measurement) under argon plasma (2.5.10-2 169 mbar, $35 \mathrm{~mA}$ ) with a High Vacuum Coater Leica EM ACE600 (Leica). Coated samples were imaged first 170 with a scanning electron microscope (SEM) equipped with a Field Emission Gun (SIGMA-HPSEM-FEG, 171 Zeiss) using high resolution "in lens" detector at $1 \mathrm{kV}$ of accelerating voltage. In a second step, some 172 samples (biofilms grown on glass fibers) were placed in a second SEM (LEO 1450VP W-SEM, Zeiss) to 173 perform EDS micro-analysis and mappings of elements ( $20 \mathrm{kV}$ of accelerating voltage at $1 \mathrm{nA}$ of sample 174 current; Oxford-Instruments INCA MAPS software)

175

176 Biofilm formation in the presence of Populus roots and ectomycorrhizae

177 Micro-propagated hybrid poplar (Populus tremula $\times$ Populus alba; INRA clone 717-1-B4) were used to 178 form mycorrhiza with L. bicolor S238N following the method of "in vitro sandwich co-culture system" 179 developed by Felten et al. (2009). A mycelium-covered cellophane membrane was placed fungus side 180 down on the roots of 3 weeks old Populus seedlings. Petri dishes were closed with Band-Aids (ensuring 181 high gas permeability). Cultures were arranged vertically, and the lower part of the dish was covered 182 with a small black plastic bag to prevent light from reaching the fungus and roots. The co-cultures were 183 incubated for one month at $24^{\circ} \mathrm{C}$ and under $16 \mathrm{hrs}$-, photoperiod then the development of mature 184 ectomycorrhizae was controlled under a stereoscope (CarlZeiss). At this stage, bacterial suspensions 185 were prepared as described above. Seedlings of Populus colonized by $L$. bicolor were transferred in a 186 large Petri dish filled with sterile PPB (Suppl. Fig. 1). The cellophane membranes were gently detached 187 by agitation ( $1 \mathrm{~min}$ ) and removed. Mycorrhizal seedlings were transferred into a double Petri dish setting 
188 containing the bacterial suspension (Suppl. Fig. 1). The double Petri dish was designed to prevent

189 contact between plant shoot and bacterial suspension. The systems were then incubated at $20^{\circ} \mathrm{C}$ with

190 gentle agitation (60 rpm) for $16 \mathrm{~h}$. Control treatments (Populus plants not inoculated with L. bicolor) were

191 treated similarly. After $16 \mathrm{~h}$ of incubation, mycorrhizal and non-mycorrhizal seedlings were transferred in

192 a new double Petri dish to be washed with $\mathrm{NaCl}$ and PPB as described above. Each sample was then

193 examined by confocal microscopy. To obtain transversal cross sections of ectomycorrhizae,

194 ectomycorrhizae were included in 4\% agarose and sectioned with a vibratome (Leica VT1200S) at a

195 thickness of $30 \mu \mathrm{m}$. For each treatment, two independent assays in duplicate were performed.

196

197 Enzymatic treatment of biofilms

198 To investigate the role of extracellular DNA (eDNA) in biofilms formation, DNase I (30 Kunitz units. $\mathrm{ml}^{-1}$

199 Qiagen) was added to $P$. fluorescens BBc6 suspensions before the incubation with glass fibers. To

200 analyze the composition of $P$. fluorescens BBc6 biofilm filaments, biofilms grown for 16 hrs on glass

201 fibers were treated with proteinase $\mathrm{K}$ (60 mAnson units. $\mathrm{ml}^{-1}$ for $1 \mathrm{hr}$, ThermoFisher), DNase I (30 Kunitz

202 units. $\mathrm{ml}^{-1}$ Qiagen), RNase A (100 Kunitz units. $\mathrm{ml}^{-1}$, ThermoFisher) or cellulase R10 (1 mg. $\mathrm{ml}^{-1}$, from

203 Trichoderma viride, SERVA). All the enzymatic treatments were performed at room temperature for

$2042 \mathrm{hrs}$. Samples were observed with laser scanning confocal microscopy (LSCM). Positive controls

205 were treated similarly. Proteinase $\mathrm{K}$ activity was verified with non-fat dried skimmed milk powder as

206 described by Nygren et al. (2007). Cellulase activity was verified with AZCL-HE-Cellulose per the

207 manufacturer's instructions $(0.2 \% \mathrm{w} / \mathrm{v}$, Megazyme). For RNase activity, total RNA from human

208 placenta $\left(1 \mu \mathrm{g} \cdot \mathrm{\mu l}^{-1}\right.$, Clontech) was treated and degradation was verified by electrophoretic migration

209 of treated and non-treated RNA (negative control) in $1 \%$-agarose gel stained with ethidium

210 bromide.

211

212

213 Results

214

215 Biofilm formation on L. bicolor S238N hyphae is widespread among soil bacteria.

216 We previously reported that the MHB P. fluorescens BBc6 forms biofilm structures on the

217 hyphae of L. bicolor S238N in in vitro setting (Miquel Guennoc et al., 2016). Using the same setting, we

218 further characterized the process by Laser Scanning Confocal Microscopy (LSCM) and Scanning

219 Electron Microscopy (SEM). The attachment of individual bacterial cells to the surface of hyphae was

220 observed after a few minutes of contact between the microorganisms (Fig. 1a, d), followed by the

221 formation of colonies (after few hours) made of a matrix of several layers of cells engulfing the hyphae 
222 (Fig. 1b, e). The colonies kept building up to form mature biofilms after about 20 hours (Fig. 1c, f).

223 Bacterial cells were encased in a dense matrix of extracellular polymeric substances (Fig. 2a) made of

224 extracellular DNA (eDNA) and proteins (Fig. 2b). Filaments that bound DAPI stain connected bacterial

225 cells to each other and anchored the biofilms to the surfaces of the hyphae (Fig. 2 a, c). The substitution

226 of $L$. bicolor hyphae by glass fibers (similar diameter) in controls also led to biofilm formation around the

227 glass fibers by $P$. fluorescens BBc6 (Fig. 3a), potentially suggesting that fungal hyphae may be nothing

228 more than a physical support used by bacteria to establish biofilms. To further test this hypothesis,

229 biofilm formation on alive and dead fungal colonies was compared. $P$. fluorescens BBc6 formed biofilms

230 on both living and dead hyphae but the distribution of the biofilms greatly differed between the two

231 treatments. Although sparse attachment was detected all over the fungal living colonies, mature biofilms

232 only developed at the actively growing margin of the fungal colony (Fig. 3b). In contrast, biofilms were

233 found all over dead fungal colonies (Fig 3c) suggesting that specific interactions between bacterial and

234 fungal cells occur during the formation of biofilms and that fungal hyphae are more than physical 235 supports.

236 To assess the degree of specificity of the physical interaction between the MHB and the ECM

237 fungus, thirteen additional cultivable bacteria spanning over a wide range of taxa highly represented in

238 soil or associated with plants, and with various ecological traits (e.g. MHB, biocontrol, pathogen, Table

239 1) were tested for their ability to form a biofilm on $L$. bicolor $S 238 \mathrm{~N}$ hyphae. All bacteria formed biofilms

240 around the hyphae at the edge of $L$. bicolor colonies (Suppl. Fig 2).

242 Skeletons of bacterial biofilms are made of DNA filaments.

243 Biofilms formed by the 14 bacterial strains on hyphae of L. bicolor S238N and on glass fibers

244 were all characterized by the presence of complex networks of filaments stained by DAPI (Suppl. Fig 2).

245 These filaments could reach a length of several hundred micrometers, and were produced, at least, by

246 the bacteria since they were also retrieved in BBc6 biofilms formed on glass fibers (Fig. 4a). The

247 filaments could only be visualized when stained with DNA specific dyes (DAPI, propidium iodide and

248 TO-PRO-3, Suppl. Table 1A). None of the other dyes tested (e.g. cellulose specific dyes) gave a 249 positive result (Suppl. Table 1A). In accordance to a DNA composition of the filaments, phosphorous 250 and nitrogen, two major components of DNA, were both detected at the surface of the filaments by 251 EDS-SEM elemental mapping (Suppl. Fig. 3). Lastly, a DNAse treatment dismantled the biofilms and 252 disrupted the filaments (Fig. 4b, c) while proteinase K, RNAse and cellulase had no visible effect (Suppl.

253 Table 1B). The filaments were also detected when $2 \%$ glucose was added to the incubation medium 254 (data not shown), indicating that the DNA filaments were not produced as a substitution strategy for 255 cellulose caused by the absence of carbon sources (Serra et al., 2013). 
257 Bacterial biofilm formation on hyphae is restricted to some fungi.

258 We next tested how widespread is the formation of bacterial biofilm on the hyphae of ten ECM 259 and non-ECM soil fungi using $P$. fluorescens BBc6 as a model bacterial strain (Table 1). The bacterial 260 strain formed biofilms on the hyphae of all ECM strains (Table 2, Suppl. Fig. 4) except the Ascomycete 261 Tuber melanosporum (Fig. 5a). Conversely, the bacterial strain produced biofilms on the surface of the 262 Basidiomycete wood decay Phanerochaete chrysosporium but not on the hyphae of the Ascomycete 263 saprophytes Aspergillus ustus AU01 and Penicillium funiculosum PF01. In these latter cases $P$. 264 fluorescens BBc6 only attached to the hyphae and never built multilayer biofilms (Fig. 5b). This 265 contrasts with Tuber hyphae on which no attachment at all was visible (Fig 5a).

267 The presence of tree roots and ectomycorrhizae modifies $P$. fluorescens $B B c 6$ behavior.

268 Roots and ectomycorrhizae are nutrient hotspots that chemoattract complex communities of 269 bacteria and that can provide to bacteria alternative habitats from the hyphosphere (Danhorn and 270 Fuqua, 2007; Bonfante and Anca, 2009). We tested whether the presence of these organs would modify 271 the behavior of $P$. fluorescens BBc6 using Poplar as a tree model organism. Poplar seedlings were 272 grown in vitro and used to produce ectomycorrhizae with L. bicolor S238N. The root system, together 273 with the associated mycelium, were then incubated with $P$. fluorescens BBc6 bacteria in a liquid setup 274 without nutrients for 16 hours to assess biofilm formation on free roots, ectomycorrhizae, short- and 275 long-distance extramatrical mycelium (Suppl. Fig. 1). Bacteria heavily colonized the surfaces of free 276 roots (Fig 6a), ectomycorrhizae (Fig. 6b), and short-distance extramatrical mycelium (i.e. emerging from 277 the ECM; Fig. 6c). By contrast, no biofilm was detected on distant hyphae (Fig 6d). To test whether this 278 absence of biofilm on distant hyphae was caused by a difference of physiology between short- and 279 long-distance extramatrical hyphae, part of the long-distance extramatrical mycelium was sampled and 280 transferred to a new plate containing a bacterial inoculum. After 16 hours, a biofilm had formed on the 281 surface of this "free" long-distance extramatrical mycelium (Fig. 6e), suggesting that the presence of 282 ectomycorrhizae but not a change in the physiological state of the fungus was responsible for the 283 change of behavior of the bacterium.

\section{Discussion \& Perspectives}

286

In various natural environments, bacteria preferentially live in biofilms that are built on abiotic 288 surfaces but also on living tissues such as roots (Flemming et al., 2016; Burmølle et al., 2012). 289 Filamentous fungi represent up to $75 \%$ of the subsurface microbial biomass with extended networks of 
$29010^{2}$ to $10^{4} \mathrm{~m}$ length per $\mathrm{g}$ of topsoil (Ritz and Young, 2004) and thus could provide immense surfaces for 291 bacteria to form biofilms. Yet, little is known on the extent on such phenomenon and the consequences

292 for the fitness of both microorganisms. Our results confirm that life as a biofilm is imprinted in the 293 genomes of a large taxonomic range of soil bacteria with various life styles and that they are likely to 294 use the surface of hyphae of fungi such as L. bicolor to build biofilms. Our data indicate that such biofilm 295 formation is likely to occur on both living and dead hyphae (Fig 3). This contrasts with previous reports 296 on the behavior of Salmonella enterica and Bacillus subtilis that only formed biofilms on living hyphae of 297 Aspergillus niger (Balbontín et al., 2014; Benoit et al., 2015). However, the use of heat treatment to kill 298 A. niger may have caused a bias by denaturing the structure of the fungal cell wall and thus preventing 299 the molecular interaction between bacterial cellulose and fungal chitin (Balbontín et al., 2014). In the 300 present study, bacteria preferentially formed biofilms at the edge of the actively growing colonies while 301 they colonized the entire fungal colonies when those were killed by fixation in paraformaldehyde (Fig 3 ) 302 or ethanol (data not shown). Formation of biofilms on the growing tips of hyphae of fungi by the 303 bacterium Burkholderia terrae was also previously reported (Nazir et al., 2014). Such differential 304 distribution could be caused by a polarized heterogeneity of the fungal colony, either in the composition 305 of the fungal cell wall (Latgé, 2007) or in the secretion of nutrients (Webster and Weber, 2007). The 306 localization of bacterial biofilms on fungal hyphae was also strongly influenced by external biotic cues 307 such as the presence of roots or ectomycorrhizae (Fig 6). Both plant roots and fungal hyphae produce 308 various exudates that chemoattract bacteria and can be used as a nutrient source (Johansson et al., 309 2004; Nazir et al., 2010; Stopnisek et al., 2016; Deveau et al., 2010) but bacteria differ in their abilities 310 to use these nutrients (Frey et al., 1997). As suggest our results, in the absence of competition between 311 bacteria, roots and ectomycorrhizae may support more bacterial biofilm formation than the fungus 312 alone. However, competition between bacteria in natural environment is likely to hinder such behavior 313 (Förster et al., 2016; Kastman et al., 2016) and it will be necessary to integrate the multiple interactions 314 that occur within multispecies mixed biofilms in further studies. In addition, settings mimicking the 315 physico-chemical properties of soils and their texture will allow to shed light onto the parameters that 316 drive bacterial-fungal interactions in soils.

If there are evident advantages for bacteria to form biofilms (Balbontín et al., 2014; Stopnisek et al., 2016), the consequences of such biofilm formation for the fungi are not clear. On one hand, bacterial biofilms could protect the fungal hyphae against grazing, toxic compounds and buffer environmental variations (Frey-Klett et al., 2011; Kuramitsu et al., 2007). On the other hand, the presence of biofilms on the growing active area of fungal colonies may limit the capacity of fungi to degrade organic matter

323 and induce a competition for nutrients between the bacterial community and the hyphae. In this second 
324 hypothesis, we expect that fungi, and particularly saprotrophic fungi, would have developed strategies to 325 block the formation of biofilms on their hyphae (Stöckli et al., 2016; Essig et al., 2014). Our data support 326 the hypothesis of de Carvalho and colleagues (de Carvalho et al., 2015), in which the mycelium of ECM 327 fungi is rather permissive to bacterial biofilm formation although exceptions like T. melanosporum exist. 328 Conversely, the inhibition of biofilm formation was more frequent among Ascomycota than 329 Basidiomycota. Whether this result reflects a reality or is biased by the existence of species-specific 330 interactions such as demonstrated for AM fungi will need to be further investigated (Toljander et al., 331 2006; Scheublin et al., 2010). The mechanisms behind the inhibition of biofilm formation by certain fungi 332 remain also to be discovered. However, our data suggest that they rely on different processes 333 depending on the fungal species. For instance, preliminary data in T. melanosporum suggest that the 334 fungus would actively inhibit biofilm formation because biofilm formation was observed on dead hyphae 335 (data not shown).

336

The large taxonomic distribution of bacteria able to form a biofilm on L. bicolor S238N hyphae suggest that there was a low degree of specificity of the bacteria towards the fungal host, and thus that the interaction potentially relied on a common mechanism. Surprisingly, we observed that all bacterial biofilms were structured by a network of filaments that seem to maintain cell together and to anchor

341 biofilms to the surface of hyphae and of glass fibers (Fig 2, 4). These skeleton-like structures were 342 highly reminiscent of the DNA extracellular traps produced by human neutrophils, plant roots and 343 amoebae to capture bacteria (de Buhr et al., 2016; Zhang et al., 2016; Tran et al., 2016). Our data also 344 strongly suggest that these skeletons would be made of eDNA. While the presence of eDNA in bacterial 345 biofilms is now well demonstrated (Flemming and Wingender, 2010), it is often seen as an anamorphous material. Yet, such eDNA organization into filaments in bacterial biofilms have been

347 sparsely reported (Böckelmann et al., 2006; Rose et al., 2015; Barnes et al., 2012; Tang et al., 2013; 348 Gloag et al., 2013; Jurcisek and Bakaletz, 2007; Novotny et al., 2013; Tran et al., 2016; Liao et al., 349 2014). Together with our data, this suggests that eDNA based skeletons are a common feature of 350 bacterial biofilms shared between Actinobacteria, Bacteroidetes, Firmicutes, $\alpha-$, $\beta$ - and $\gamma$ 351 Proteobacteria.

352 The role of such eDNA filaments in the formation and functioning of bacterial biofilms remains 353 elusive. Consistently with the hypothesis that eDNA would serve as a cohesive molecule that maintain 354 bacterial cells together and anchor them to a surface (Das et al., 2010; Tang et al., 2013), the addition 355 of DNAse at the inoculation time of the bacteria fully blocked the formation of biofilm (data not shown). 356 Although eDNA skeletons may have additional functions in bacterial biofilms (Gloag et al., 2013; 357 Doroshenko et al., 2014), it is noteworthy that a broad range of organisms belonging to the Animal, 
358 Plant, Protist and Eubacteria Kingdoms all uses DNA for additional purposes than coding genetic 359 information. Thus DNA, thanks to its adhesive physico-chemical properties, may have an additional 360 universal function that has been overlooked so far.

361

Overall, our work indicates that soil fungi, and most particularly ECM fungi, may often serve as 363 a support to biofilm formation for a wide range of soil bacteria, in addition to be a source of nutrients and 364 a potential vector for bacterial mobility. Such biofilm formation on fungal hyphae is likely to be 365 modulated by numerous biotic factors including roots exudates and fungal activities. Besides the 366 importance of eDNA based filaments for the building of these biofilms, the molecular dialog involved in 367 the formation of biofilms on fungal hyphae and the nature of the interaction engaged between the 368 microorganisms will need to be further investigated.

\section{Acknowledgements}

372 This work was supported by the French National Research Agency through the Laboratory of 373 Excellence ARBRE (ANR-11-LABX-0002-01) and by the Plant-Microbe Interfaces Scientific Focus Area 374 in the Genomic Science Program, the Office of Biological and Environmental Research in the U.S. 375 Department of Energy Office of Science. Oak Ridge National Laboratory is managed by UT-Battelle, 376 LLC, for the U.S. Department of Energy under contract DE-AC05-000R22725. We would like to thank 377 Francis Martin for helpful discussions and comments on the manuscript. We thank Frédéric Guinet for 378 helping with the preparation of in vitro mycorrhized seedlings, Anais Gilet for providing fungal strains, 379 and Béatrice Palin for technical support along the experiments. 


\section{References}

383 Balbontín R, Vlamakis H, Kolter R. (2014). Mutualistic interaction between Salmonella enterica and

384 Aspergillus niger and its effects on Zea mays colonization. Microb Biotechno/ 7: 589-600.

385 Barnes AMT, Ballering KS, Leibman RS, Wells CL, Dunny GM. (2012). Enterococcus faecalis Produces

386 Abundant Extracellular Structures Containing DNA in the Absence of Cell Lysis during Early Biofilm

387 Formation. MBio 3: e00193-12-e00193-12.

388 Benoit I, van den Esker MH, Patyshakuliyeva A, Mattern DJ, Blei F, Zhou M, et al. (2015). Bacillus

389 subtilis attachment to Aspergillus niger hyphae results in mutually altered metabolism. Environ Microbiol

390 17: 2099-2113.

391 Böckelmann U, Janke A, Kuhn R, Neu TR, Wecke Jãf, Lawrence JR, et al. (2006). Bacterial

392 extracellular DNA forming a defined network-like structure. FEMS Microbiol Lett 262: 31-38.

393 Bonfante P, Anca IA. (2009). Plants, mycorrhizal fungi, and bacteria: a network of interactions. Annu

394 Rev Microbiol 63: 363-383.

395 de Buhr N, von Köckritz-Blickwede M, ckritz-Blickwede M. (2016). How Neutrophil Extracellular Traps

396 Become Visible. J Immunol Res 2016: 1-13.

397 Burmølle M, Kjøller A, Sørensen SJ. (2012). An invisible workforce: biofilms in the soil. In: Lear G, Lewis

398 GD (eds). Microbial Biofilms: current research and applications. Horizon Scientific Press, pp 61-71.

399 de Carvalho MP, Türck P, Abraham W-R. (2015). Secondary Metabolites Control the Associated

400 Bacterial Communities of Saprophytic Basidiomycotina Fungi. Microbes Environ 30: 196-8.

401 Danhorn T, Fuqua C. (2007). Biofilm Formation by Plant-Associated Bacteria. Annu Rev Microbio/ 61:

402 401-422.

403 Das T, Sharma PK, Busscher HJ, van der Mei HC, Krom BP. (2010). Role of extracellular DNA in initial

404 bacterial adhesion and surface aggregation. Appl Environ Microbiol 76: 3405-8.

405 Deveau A, Brulé C, Palin B, Champmartin D, Rubini P, Garbaye J, et al. (2010). Role of fungal

406 trehalose and bacterial thiamine in the improved survival and growth of the ectomycorrhizal fungus

407 Laccaria bicolor S238N and the helper bacterium Pseudomonas fluorescens BBc6R8. Environ Microbiol

408 Rep 2: 560-8.

409 Deveau A, Labbé J. (2017). Mycorrhiza Helper Bacteria. In: Martin F (ed). Molecular Mycorrhizal

410 Symbiosis. John Wiley \& Sons, pp 437-440.

411 Doroshenko N, Tseng BS, Howlin RP, Deacon J, Wharton JA, Thurner PJ, et al. (2014). Extracellular

412 DNA Impedes the Transport of Vancomycin in Staphylococcus epidermidis Biofilms Preexposed to

413 Subinhibitory Concentrations of Vancomycin. Antimicrob Agents Chemother 58: 7273-7282.

414 Essig A, Hofmann D, Münch D, Gayathri S, Künzler M, Kallio PT, et al. (2014). Copsin, a Novel Peptide-

415 based Fungal Antibiotic Interfering with the Peptidoglycan Synthesis. J Bio/ Chem 289: 34953-34964. 
416 Felten J, Kohler A, Morin E, Bhalerao RP, Palme K, Martin F, et al. (2009). The ectomycorrhizal fungus

417 Laccaria bicolor stimulates lateral root formation in poplar and Arabidopsis through auxin transport and 418 signaling. Plant Physiol 151: 1991-2005.

419 Flemming H-C, Wingender J. (2010). The biofilm matrix. Nat Rev Microbio/ 8: 623.

420 Flemming H-C, Wingender J, Szewzyk U, Steinberg P, Rice SA, Kjelleberg S. (2016). Biofilms: an

421 emergent form of bacterial life. Nat Rev Microbiol 14: 563-575.

422 Förster TM, Mogavero S, Dräger A, Graf K, Polke M, Jacobsen ID, et al. (2016). Enemies and brothers

423 in arms: Candida albicans and gram-positive bacteria. Cell Microbio/ 18: 1709-1715.

424 Frey-Klett P, Burlinson P, Deveau A, Barret M, Tarkka M, Sarniguet A. (2011). Bacterial-Fungal

425 Interactions: Hyphens between Agricultural, Clinical, Environmental, and Food Microbiologists. Microbiol

426 Mol Biol Rev 75: 583-609.

427 Frey-Klett P, Chavatte M, Clausse ML, Courrier S, Le Roux C, Raaijmakers J, et al. (2005).

428 Ectomycorrhizal symbiosis affects functional diversity of rhizosphere fluorescent pseudomonads. New

429 Phytol 165: 317-328.

430 Frey-Klett P, Garbaye J, Tarkka M. (2007). The mycorrhiza helper bacteria revisited. New Phytol 176:

431 22-36.

432 Frey P, Frey-Klett P, Garbaye J, Berge O, Heulin T. (1997). Metabolic and genotypic fingerprinting of

433 fluorescent Pseudomonads associated with the Douglas fir-Laccaria bicolor mycorrhizosphere. Appl

434 Env Microbio/ 63: 1852-1860.

435 Gloag ES, Turnbull L, Huang A, Vallotton P, Wang H, Nolan LM, et al. (2013). Self-organization of

436 bacterial biofilms is facilitated by extracellular DNA. Proc Natl Acad Sci U S A 110: 11541-6.

437 Hover T, Maya T, Ron S, Sandovsky H, Shadkchan Y, Kijner N, et al. (2016). Mechanisms of bacterial

438 (Serratia marcescens) attachment to, migration along, and killing of fungal hyphae. Appl Environ

439 Microbiol 82: 2585-2594.

440 Johansson JF, Paul LR, Finlay RD. (2004). Microbial interactions in the mycorrhizosphere and their

441 significance for sustainable agriculture. FEMS Microbiol Ecol 48: 1-13.

442 Jurcisek JA, Bakaletz LO. (2007). Biofilms Formed by Nontypeable Haemophilus influenzae In Vivo

443 Contain both Double-Stranded DNA and Type IV Pilin Protein. J Bacterio/ 189: 3868-3875.

444 Kastman EK, Kamelamela N, Norville JW, Cosetta CM, Dutton RJ, Wolfe BE. (2016). Biotic Interactions

445 Shape the Ecological Distributions of Staphylococcus Species. MBio 7: e01157-16.

446 Kuramitsu HK, He X, Lux R, Anderson MH, Shi W. (2007). Interspecies interactions within oral microbial

447 communities. Microbiol Mol Biol Rev 71: 653-70.

448 Latgé J-P. (2007). The cell wall: a carbohydrate armour for the fungal cell. Mol Microbio/ 66: 279-290.

449 Leveau JHJ, Preston GM. (2008). Bacterial mycophagy: definition and diagnosis of a unique bacterial- 
450 fungal interaction. New Phytol 177: 859-76.

451 Li L, Yang M, Luo J, Qu Q, Chen Y, Liang L, et al. (2016). Nematode-trapping fungi and fungus-

452 associated bacteria interactions: the role of bacterial diketopiperazines and biofilms on Arthrobotrys

453 oligospora surface in hyphal morphogenesis. Environ Microbiol 18: 3827-3839.

454 Liao S, Klein Ml, Heim KP, Fan Y, Bitoun JP, Ahn S-J, et al. (2014). Streptococcus mutans Extracellular

455 DNA Is Upregulated during Growth in Biofilms, Actively Released via Membrane Vesicles, and

456 Influenced by Components of the Protein Secretion Machinery. J Bacterio/ 196: 2355-2366.

457 Lindahl BD, Tunlid A. (2015). Ectomycorrhizal fungi - potential organic matter decomposers, yet not

458 saprotrophs. New Phytol 205: 1443-1447.

459 Martin F, Aerts A, Ahrén D, Brun A, Danchin EGJ, Duchaussoy F, et al. (2008). The genome of Laccaria

460 bicolor provides insights into mycorrhizal symbiosis. Nature 452: 88-92.

461 Miquel Guennoc C, Rose C, Guinnet F, Miquel I, Labbé J, Deveau A. (2016). A New Method for

462 Qualitative Multiscale Analysis of Bacterial Biofilms on Filamentous Fungal Colonies Using Confocal

463 and Electron Microscopy 3 . Laser Scanning Confocal Microscopy analysis of the biofilm formation. $J$

464 Vis Exp epub.

465 Nazir R, Tazetdinova DI, van Elsas JD. (2014). Burkholderia terrae BS001 migrates proficiently with

466 diverse fungal hosts through soil and provides protection from antifungal agents. Front Microbio/ 5: 598.

467 Nazir R, Warmink JA, Boersma H, van Elsas JD. (2010). Mechanisms that promote bacterial fitness in

468 fungal-affected soil microhabitats. FEMS Microbiol Ecol 71: 169-185.

469 Novotny LA, Amer AO, Brockson ME, Goodman SD, Bakaletz LO, Campana S, et al. (2013). Structural

470 Stability of Burkholderia cenocepacia Biofilms Is Reliant on eDNA Structure and Presence of a Bacterial

471 Nucleic Acid Binding Protein Coenye T (ed). PLoS One 8: e67629.

472 Nygren CMR, Edqvist J, Elfstrand M, Heller G, Taylor AFS. (2007). Detection of extracellular protease

473 activity in different species and genera of ectomycorrhizal fungi. Mycorrhiza 17: 241-248.

474 Otto S, Bruni EP, Harms H, Wick LY. (2016). Catch me if you can: dispersal and foraging of Bdellovibrio

475 bacteriovorus 109J along mycelia. ISME J. e-pub ahead of print, doi: 10.1038/ismej.2016.135.

476 Pion M, Spangenberg JE, Simon A, Bindschedler S, Flury C, Chatelain A, et al. (2013). Bacterial

477 farming by the fungus Morchella crassipes. Proc Biol Sci 280: 20132242.

478 Ritz K, Young IM. (2004). Interactions between soil structure and fungi. Mycologist 18: 52-59.

479 Rose SJ, Babrak LM, Bermudez LE, Griffith D, Aksamit T, Brown-Elliott B, et al. (2015). Mycobacterium

480 avium Possesses Extracellular DNA that Contributes to Biofilm Formation, Structural Integrity, and

481 Tolerance to Antibiotics Coenye T (ed). PLoS One 10: e0128772.

482 Rousk J, Bengtson P. (2014). Microbial regulation of global biogeochemical cycles. Front Microbiol 5:

483103. 
484 Scheublin TR, Sanders IR, Keel C, van der Meer JR. (2010). Characterisation of microbial communities 485 colonising the hyphal surfaces of arbuscular mycorrhizal fungi. ISME J 4: 752-763.

486 Schindelin J, Arganda-Carreras I, Frise E, Kaynig V, Longair M, Pietzsch T, et al. (2012). Fiji: an open-

487 source platform for biological-image analysis. Nat Meth 9: 676-682.

488 Serra DO, Richter AM, Hengge R. (2013). Cellulose as an architectural element in spatially structured 489 Escherichia coli biofilms. J Bacterio/ 195: 5540-54.

490 Smith S, Read D. (2008). Mycorrhizal Symbiosis. 3rd ed. Academic Press: London.

491 Stöckli M, Lin C-W, Sieber R, Plaza DF, Ohm RA, Künzler M. (2016). Coprinopsis cinerea intracellular

492 lactonases hydrolyze quorum sensing molecules of Gram-negative bacteria. Fungal Genet Biol. e-pub

493 ahead of print, doi: 10.1016/j.fgb.2016.07.009.

494 Stopnisek N, Zühlke D, Carlier A, Barberán A, Fierer N, Becher D, et al. (2016). Molecular mechanisms

495 underlying the close association between soil Burkholderia and fungi. ISME J 10: 253-264.

496 Tang L, Schramm A, Neu TR, Revsbech NP, Meyer RL. (2013). Extracellular DNA in adhesion and

497 biofilm formation of four environmental isolates: a quantitative study. FEMS Microbiol Ecol 86: 394-403.

498 Toljander JF, Artursson V, Paul LR, Jansson JK, Finlay RD. (2006). Attachment of different soil bacteria

499 to arbuscular mycorrhizal fungal extraradical hyphae is determined by hyphal vitality and fungal species.

500 FEMS Microbiol Lett 254: 34-40.

501 Tran TM, Maclntyre A, Hawes M, Allen C, Wen F, VanEtten H, et al. (2016). Escaping Underground

502 Nets: Extracellular DNases Degrade Plant Extracellular Traps and Contribute to Virulence of the Plant

503 Pathogenic Bacterium Ralstonia solanacearum He SY (ed). PLOS Pathog 12: e1005686.

504 Warmink JA, van Elsas JD. (2009). Migratory Response of Soil Bacteria to Lyophyllum sp. Strain

505 Karsten in Soil Microcosms. Appl Environ Microbiol 75: 2820-2830.

506 Warmink JA, Nazir R, van Elsas JD. (2009). Universal and species-specific bacterial 'fungiphiles' in the 507 mycospheres of different basidiomycetous fungi. Environ Microbio/ 11: 300-12.

508 Webster J, Weber RWS. (2007). Introduction to Fungi. Third. Cambridge University Press: New York.

509 Zhang X, Zhuchenko O, Kuspa A, Soldati T, Brinkmann V, Brinkmann V, et al. (2016). Social amoebae

510 trap and kill bacteria by casting DNA nets. Nat Commun 7: 10938.

511

512 
bioRxiv preprint doi: https://doi.org/10.1101/130740; this version posted April 28,2017 . The copyright holder for this preprint (which was not certified by peer review) is the author/funder, who has granted bioRxiv a license to display the preprint in perpetuity. It is made available under aCC-BY-NC-ND 4.0 International license.

\section{Tables \& Figure legends.}

\section{4}

515 Table 1. List and characteristics of the microbial strains.

\begin{tabular}{|c|c|c|c|c|}
\hline Microbial strains & Taxonomic classification & $\begin{array}{l}\text { Gram } \\
\text { type }\end{array}$ & Ecological trait & References \\
\hline \multicolumn{5}{|l|}{ Bacterial strains } \\
\hline $\begin{array}{l}\text { Pseudomonas } \\
\text { fluorescens BBc6 }\end{array}$ & $\begin{array}{l}\text { Gamma-proteobacteria, } \\
\text { Pseudomonadaceae }\end{array}$ & - & $\begin{array}{l}\text { Mycorrhiza helper } \\
\text { bacterium }\end{array}$ & $\begin{array}{l}\text { Duponnois \& } \\
\text { Garbaye } 1991\end{array}$ \\
\hline $\begin{array}{l}\text { Pseudomonas protegens } \\
\text { Pf5 }\end{array}$ & $\begin{array}{l}\text { Gamma-proteobacteria, } \\
\text { Pseudomonadaceae }\end{array}$ & - & Biocontrol & $\begin{array}{l}\text { Howell \& } \\
\text { Stipanovic } 1979\end{array}$ \\
\hline $\begin{array}{l}\text { Pseudomonas } \\
\text { fluorescens SBW25 }\end{array}$ & $\begin{array}{l}\text { Gamma-proteobacteria, } \\
\text { Pseudomonadaceae }\end{array}$ & - & $\begin{array}{l}\text { Plant Growth } \\
\text { Promoting \& } \\
\text { biocontrol }\end{array}$ & Bailey et al 1995 \\
\hline $\begin{array}{l}\text { Pseudomonas } \\
\text { fluorescens Pf29A }\end{array}$ & $\begin{array}{l}\text { Gamma-proteobacteria, } \\
\text { Pseudomonadaceae }\end{array}$ & - & Biocontrol & $\begin{array}{l}\text { Chapon et al } \\
2002\end{array}$ \\
\hline Pseudomonas sp. GM18 & $\begin{array}{l}\text { Gamma-proteobacteria, } \\
\text { Pseudomonadaceae }\end{array}$ & - & $\begin{array}{l}\text { Mycorrhiza helper } \\
\text { bacterium }\end{array}$ & Labbé et al 2014 \\
\hline $\begin{array}{l}\text { Pseudomonas syringae } \\
\text { pv. tomato DC } 3000\end{array}$ & $\begin{array}{l}\text { Gamma-proteobacteria, } \\
\text { Pseudomonadaceae }\end{array}$ & - & Plant pathogen & Cuppels 1986 \\
\hline Dyella sp. E3BF9_7 & $\begin{array}{l}\text { Gamma-proteobacteria, } \\
\text { Rhodonobacteraceae }\end{array}$ & - & $\begin{array}{l}\text { White rot associated } \\
\text { bacterium }\end{array}$ & Hervé et al 2016 \\
\hline $\begin{array}{l}\text { Collimonas fungivorans } \\
\text { Ter331 }\end{array}$ & $\begin{array}{l}\text { Beta-proteobacteria, } \\
\text { Oxalobacteraceae }\end{array}$ & - & $\begin{array}{l}\text { Mycophagous } \\
\text { bacterium }\end{array}$ & $\begin{array}{l}\text { de Boer et al } \\
2004\end{array}$ \\
\hline $\begin{array}{l}\text { Burkholderia ginsengisoli } \\
\text { E3BF7_7 }\end{array}$ & $\begin{array}{l}\text { Beta-proteobacteria, } \\
\text { Burkholderiaceae }\end{array}$ & - & $\begin{array}{c}\text { White rot associated } \\
\text { bacterium }\end{array}$ & Hervé et al 2016 \\
\hline $\begin{array}{l}\text { Sinorhizobium meliloti } \\
1021\end{array}$ & $\begin{array}{l}\text { Alpha-proteobacteria, } \\
\text { Rhizobiaceae }\end{array}$ & - & $\begin{array}{l}\text { Nitrogen fixing plant } \\
\text { symbiont }\end{array}$ & Maede et al 1982 \\
\hline $\begin{array}{l}\text { Pedobacter sp. } \\
\text { D3AIN17A }\end{array}$ & $\begin{array}{c}\text { Bacteroidetes, } \\
\text { Sphingobacteriaceae }\end{array}$ & - & $\begin{array}{c}\text { Black truffle } \\
\text { associated bacterium }\end{array}$ & $\begin{array}{l}\text { Deveau et al } \\
\text { unpublished }\end{array}$ \\
\hline $\begin{array}{l}\text { Paenibacillus sp. F2001- } \\
\mathrm{L}\end{array}$ & Firmicutes, Paenibacillaceae & + & $\begin{array}{c}\text { Endohyphal strain of } \\
\text { L. bicolor }\end{array}$ & $\begin{array}{l}\text { Bertaux et al } \\
2003\end{array}$ \\
\hline Bacillus subtilis MB3 & Firmicutes, Bacillaceae & + & $\begin{array}{l}\text { Mycorrhiza helper } \\
\text { bacterium }\end{array}$ & $\begin{array}{l}\text { Duponnois \& } \\
\text { Garbaye } 1991\end{array}$ \\
\hline Bacillus sp. EJP109 & Firmicutes, Bacillaceae & + & $\begin{array}{l}\text { Mycorrhiza helper } \\
\text { bacterium }\end{array}$ & Poole et al 2001 \\
\hline \multicolumn{5}{|l|}{ Fungal strains } \\
\hline Laccaria bicolor S238N & $\begin{array}{l}\text { Basidiomycota, } \\
\text { Tricholomataceae }\end{array}$ & $n / a$ & ECM & Martin et al 2008 \\
\hline Lactarius quietus & Basidiomycota, Russulaceae & $\mathrm{n} / \mathrm{a}$ & ECM & INRA Nancy \\
\hline $\begin{array}{l}\text { Hebeloma } \\
\text { cylindrosporum }\end{array}$ & $\begin{array}{l}\text { Basidiomycota, } \\
\text { Cortinariaceae } \\
\end{array}$ & $n / a$ & ECM & Kohler et al 2015 \\
\hline Piloderma croceum & Basidiomycota, Atheliaceae & $\mathrm{n} / \mathrm{a}$ & ECM & Kohler et al 2015 \\
\hline $\begin{array}{l}\text { Phanerochaete } \\
\text { chrysosporium RP78 }\end{array}$ & $\begin{array}{c}\text { Basidiomycota, } \\
\text { Phanerochaeteceae }\end{array}$ & $\mathrm{n} / \mathrm{a}$ & $\begin{array}{l}\text { saprotroph } \\
\text { (white rot) }\end{array}$ & Hervé et al 2016 \\
\hline Thelephora terrestris & $\begin{array}{l}\text { Basidiomycota, } \\
\text { Thelephoraceae }\end{array}$ & $\mathrm{n} / \mathrm{a}$ & ECM & INRA Nancy \\
\hline $\begin{array}{l}\text { Tuber melanosporum } \\
\text { Mel28 }\end{array}$ & Ascomycota, Tuberaceae & $\mathrm{n} / \mathrm{a}$ & ECM & Martin et al 2010 \\
\hline $\begin{array}{l}\text { Elaphomyces granulatus } \\
\text { PEP }\end{array}$ & $\begin{array}{c}\text { Ascomycota, } \\
\text { Elaphomycetaceae }\end{array}$ & $\mathrm{n} / \mathrm{a}$ & ECM & $\begin{array}{l}\text { Quandt et al } \\
2015\end{array}$ \\
\hline $\begin{array}{l}\text { Penicillium funiculosum } \\
\text { PF01 }\end{array}$ & Ascomycota, Aspergillaceae & $\mathrm{n} / \mathrm{a}$ & $\begin{array}{c}\text { Saprotroph } \\
\text { \& plant pathogen }\end{array}$ & INRA Nancy \\
\hline
\end{tabular}




\section{6}

\begin{tabular}{|l|l|l|l|l|}
\hline Aspergillus ustus AU01 & Ascomycota, Aspergillaceae & n/a & Saprotroph & INRA Nancy \\
\hline
\end{tabular}

517 Table 2. Taxonomy and trophic status of fungi tested for bacterial (P. fluorescens BBc6) biofilm

518 formation.

\begin{tabular}{|l|c|c|c|}
\hline \multicolumn{1}{|c|}{$\begin{array}{c}\text { Trophic status } \\
\text { \& taxonomy }\end{array}$} & Total of strains tested & Biofilm positive & Biofilm negative \\
\hline ECM & 7 & 6 & 1 \\
Ascomycota & 2 & 1 & 1 \\
Basidiomycota & 5 & 5 & 0 \\
\hline Saprotroph & 3 & 1 & 2 \\
Ascomycota & 2 & 0 & 2 \\
Basidiomycota & 1 & 1 & 0 \\
\hline Taxonomy & & 1 & 3 \\
Ascomycota & 4 & 6 & 0 \\
Basidiomycota & 6 & & \\
\hline
\end{tabular}

519

520 


\section{Figures}

522

523

524

525

526

527

528

529

530

531

532

533

534

535

536

537

538

539

540

541

542

543

544

545

546

547

548

549

550

551

552

553

554

555

556

557

558

559

560

561

562

563

564

565

566

567

568

569

570
Figure 1. Time course of $P$. fluorescens BBc6 biofilm formation on the surface of $L$. bicolor $S 238 \mathrm{~N}$ hyphae. Confocal microscopy images showing the spatial localization of BBc6 biofilms (green) on $L$. bicolor S238N hyphae (red) and their development over time from early stage attachment (30 min ; a,d) to colony formation $(6 \mathrm{~h} ; \mathrm{b}, \mathrm{e})$ and mature biofilms $(20 \mathrm{~h} ; \mathrm{c}, \mathrm{f})$. The yellow arrow points toward the external edge of the fungal colony. Bottom panels are zoom in of the areas highlighted by white rectangles in top panels. Fungal hyphae were stained with Wheat Germ Agglutin-AlexaFluor 633 and bacterial cells were GFP-tagged. Images were obtained via 2D maximum intensity projection of 3D confocal microscopy images $(z=40.5 \mu \mathrm{m}(\mathrm{a}), 30 \mu \mathrm{m}(\mathrm{b}), 43.5 \mu \mathrm{m}(\mathrm{c}))$. Magnification 40x.

Figure 2. Characterization of the matrix components of $P$. fluorescens BBc6 biofilms on the surface of L. bicolor S238N. A. Scanning electron microscopy image of $24 \mathrm{~h}$ old biofilm showing bacterial cells (*) and fungal hyphae (f) encased in a matrix made of aggregates and filaments. B. Confocal microscopy image showing the presence of proteins aggregates (white) and eDNA (blue) in the matrix of $16 \mathrm{~h}$ old $P$. fluorescens BBc6 (green) biofilm on L. bicolor S238N hyphae (red). Proteins and eDNA were stained with SYPRO Ruby and DAPI, respectively. Magnification 40x. C. Confocal microscopy image showing the presence of filaments stained by DAPI (yellow arrows) connecting hyphae to bacterial cells. Magnification 40x.

Figure 3. Distribution of $P$. fluorescens BBc6 biofilms on abiotic and biotic surfaces. A. Confocal microscopy image showing $P$. fluorescens BBc6 biofilm formed over glass fibers after 22 hours. Magnification 40x. B, C. Confocal microscopy images showing differential distribution $P$. fluorescens BBc6 biofilms formed over alive (B) and dead hyphae (C) of L. bicolor S238N. L. bicolor S238N hyphae were killed by immersing fungal colonies in 3\% paraformaldehyde for $1 \mathrm{~h}$ followed by 3 repeated washes in phosphate buffer before inoculating bacteria. Images were obtained via 2D maximum intensity projection of 3D mosaic confocal microscopy images $(z=69 \mu \mathrm{m}(\mathrm{b}), 32 \mu \mathrm{m}(\mathrm{c}))$. Magnification 10x.

Figure 4. Production of eDNA filaments by $P$. fluorescens BBc6 during biofilm formation. A. Confocal images showing $\mathrm{mm}$ long filament structures stained by DAPI DNA marker in biofilms of $P$. fluorescens built on glass fibers. Magnification 40x. B, C. Confocal images of TO-PRO-3 stained filaments in $P$. fluorescens BBc6 $16 \mathrm{hrs}$ old biofilm on glass fibers before (B) and after DNAse treatment (C). White arrows point at filament positions. Magnification $10 \mathrm{x}$.

Figure 5. $P$. fluorescens BBc6 does not form biofilm on the hyphae of the Ascomycetes Tuber melanosporum (A) and Aspergillus ustus (B) after 16hrs of interaction. T. melanosporum hyphae were stained with Wheat Germ Agglutin-AlexaFluor 633 (red). Due to poor staining of $A$. ustus hyphae by Wheat Germ Agglutin-AlexaFluor 633, A. ustus hyphae were imaged using transmitted light. Magnification 40x.

Figure 6. Differential distribution of $P$. fluorescens $\mathrm{BB} 66$ biofilms on Poplar roots, ectomycorhizae and extramatrical mycelium after $16 \mathrm{hrs}$ of interaction. A. Confocal image showing P. fluorescens BBc6 (green) colonization of Poplar roots (blue). B. Transversal section of L. bicolor S238N (red)- Poplar (blue) ectomycorrhizae colonized by $P$. fluorescens BBc6 (green). C. Confocal image of $L$. bicolor S238N extramatrical hyphae (blue) surrounding Poplar root (red) and colonized by $P$. fluorescens BBc6 (green). D. Confocal image showing L. bicolor S238N extramatrical hyphae (red) distant from root and ectomycorhizae that are not colonized by $P$. fluorescens BBc6 (green) in the presence of Poplar root system. E. Confocal image showing L. bicolor S238N extramatrical hyphae (red) distant from root and ectomycorhizae colonized by P. fluorescens BBc6 (green) in the absence of Poplar root system. Magnification 40x. 
571 L. bicolor S238N hyphae were stained with Wheat Germ Agglutin-AlexaFluor 633 (red), Poplar root cells 572 and eDNA were visualized with a combination of DAPI staining and autofluorescence (blue) and 573 bacterial cells were GFP-tagged (green). All images were obtained via 2D maximum intensity projection 574 of 3D confocal microscopy images $(z=60 \mu \mathrm{m}(\mathrm{a}), 57 \mu \mathrm{m}$ (b), $68 \mu \mathrm{m}$ (c), $46 \mu \mathrm{m}(\mathrm{d}), 29 \mu \mathrm{m}(\mathrm{e}))$. 575 Magnification 40x.

576 mr: main root, rh: root hairs, exm :extramatrical mycelium.

577

578

579

Supplemental Fig. 1. Experimental setup used to analyze biofilm formation during tripartite interaction 580 between $P$. fluorescens BBc6, L. bicolor S238N and Populus tremula $x$ alba. Mycorhizal seedlings were 581 first produced using the in vitro sandwich co-culture system (Felten et al. 2009). One-month-old 582 mycorrhizal seedlings were then used to analyze in vitro biofilm formation on ectomycorrhizae, non583 mycorrhized roots, and extramatrical mycelium.

585 Supplemental Fig. 2. Biofilm formation of the hyphae of $L$. bicolor $S 238 \mathrm{~N}$ by bacteria as visualized by 586 confocal microscopy. Fungal hyphae were stained with Wheat Germ Agglutin-AlexaFluor 633 (red) and 587 bacteria with DAPI (blue), except $P$. fluorescens BBc6, B. ginsengisoli E3BF7_7 and Dyella sp. 588 E3BF9_7 that constitutively expressed GFP (green). eDNA filaments are highlighted by yellow arrows in 589 caption boxes. Images were obtained via 2D maximum intensity projection of 3D confocal microscopy 590 images Magnification 40x.

591

592

593

594

595

Supplemental Fig. 3. Elemental mapping of $P(b, c), N(d, e)$ and $S i(f, g)$ of BBc6 filaments and biofilm matrix on glass fibers obtained by EDS Spectrometry coupled to SEM imagery. Electron image: a, raw elemental map; b, d and f, overlay of electron image and elemental map : c, e, $g$

Supplemental Fig. 4. Biofilm formation by $P$. fluorescens BBc6-GFP on hyphae of soil fungi. Fungal hyphae were stained with Wheat Germ Agglutin-AlexaFluor 633 (red), bacterial cells were GFP-tagged and eDNA was stained with DAPI (blue). Due to poor staining of $T$. terrestris, A. ustus and $P$. funiculosum hyphae by Wheat Germ Agglutin-AlexaFluor 633, hyphae of these fungi were imaged using 600 transmitted light, coloured in red. Images were obtained via 2D maximum intensity projection of 3D 601 confocal microscopy images. Magnification 40x.

602 


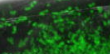

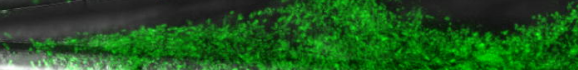

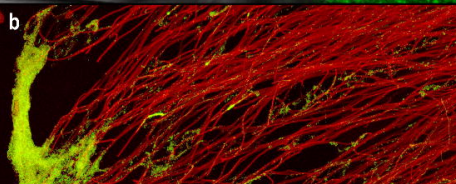

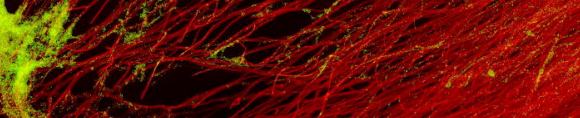

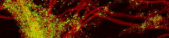

i

c

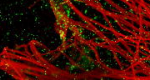

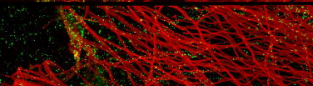

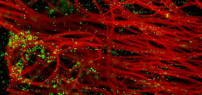

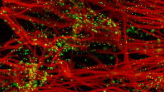

x

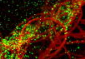

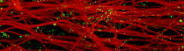




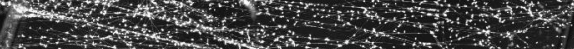

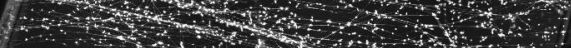

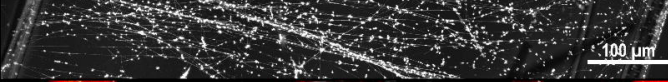

b $2-10$

C

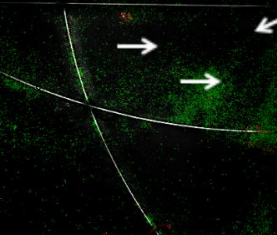




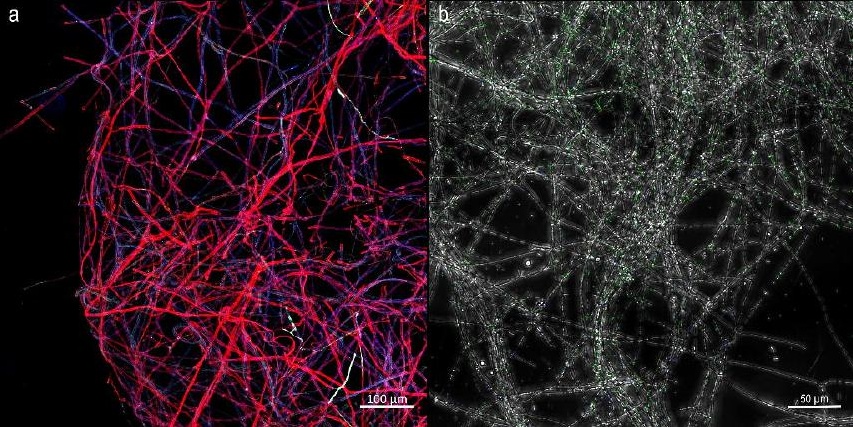


c

a

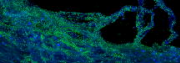

$25 \mu \mathrm{m}$

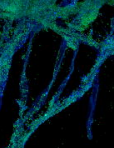

b

$\mathrm{mr}$

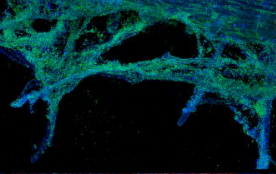

$50 \mu \mathrm{m}$ exm

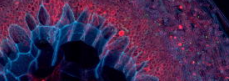
(3)

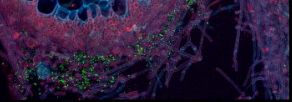

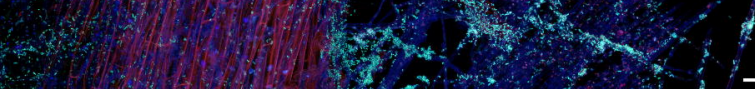

d

e. 1,4
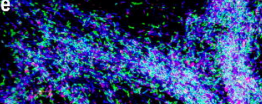

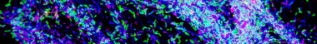
35 .

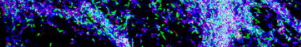

